\title{
X-raying planktonic foraminifera
}

\author{
P. N. LEARY \& M. B. HART \\ Department of Geological Sciences, Plymouth Polytechnic, Drake Circus, Plymouth, Devon \\ PL4 8AA
}

\begin{abstract}
X-raying planktonic foraminifera provides a rapid, efficient and cost-effective method of recording many specimens for biometric analysis. A new approach is here proposed which replaces previous complicated techniques.
\end{abstract}

\section{INTRODUCTION}

$\mathrm{X}$-raying planktonic foraminifera provides a rapid and efficient method of recording many specimens for biometric analysis without the high costs associated with scanning electron microscopy. It permits the study of ontogenic studies of involute species, pore diameter (Bé et al., 1969) and evolution (Arnold, 1982). Methods of X-raying foraminifera have previously been proposed (Hedley, 1957; Bé et al., 1969; Arnold, 1982) but the techniques are complicated and the films unavailable in the United Kingdom.

A new approach is proposed using as examples, Rotalipora cushmani (Morrow) specimens from the latest Cenomanian of DSDP Leg 80, Site 551 Goban Spur and Dover.

\section{METHOD}

Using a Scannex 150D X-ray machine with Kodak MX5 high resolution film $(9 \times 12 \mathrm{cms})$ and an exposure of $3.4 \mathrm{~mA}$ minutes $(20 \mathrm{kV})$ at a distance of $30 \mathrm{cms}$ from the light source, several hundred specimens may be photographed in a short time. The large distance from the source $(30 \mathrm{cms})$ minimises the blurring of the image as the rays are practically parallel.

The specimens are mounted on an X-ray cell (Fig. 1), the 'cling-film' being transparent to $\mathrm{X}$-rays, and are placed in the required orientation using a paint brush and a strong solution of gum tragacanth. The cell is small to minimise the problems of the specimens moving if the former is inadvertently knocked prior to exposure. Three cells are fitted on one film $(9 \times 12 \mathrm{cms})$, the number of films exposed each time depending on the exposure field in the X-ray machine. A record of the sample number of each cell (marked with lead alphabet labels) is made.

After developing, the films are cut and each picture of the cell mounted between two glass slides, which are then tightly taped to minimise shrinkage of the film.

The XI image can then be analysed optically using a standard transmitted light microscope and the relevant parameters measured using a graticule.

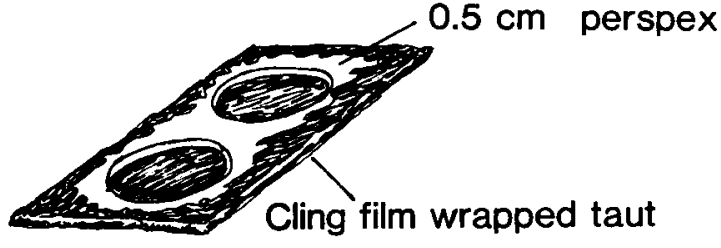

under one surface and affixed to the outer edge

Fig. 1. The X-ray cell.

\section{CONCLUSION}

The method is simple, cost effective, quick, does not damage the specimens and is useful for biometric analysis. In addition, it illustrates test overgrowths present on some specimens. For example, those of $R$. cushmani from the deep water section of Leg 80, Site 551 on the Goban Spur (Pl. 1, fig. 1) show little or no test overgrowth in contrast to the coeval ones from the shallower water sequence of the Anglo-Paris Basin at Dover (Pl. 1, fig. 2). The details of the latter tests may be attained by increasing the exposure time to $4.0 \mathrm{~mA}$ minutes.

Manuscript received November 1987

Manuscript accepted January 1988

\section{REFERENCES}

Arnold, A. J. 1982. Techniques for biometric analysis of foraminifera. Proc. 3rd North American Paleontological Convention, 1, 13-15.

Bé A. W. H., Jongebloed, W. L. \& McIntyre, A. 1969. X-ray microscopy of Recent Planktonic foraminifera. J. Paleont., Chicago, 43 (6), 1384-1396.

Hedley, R. H. 1957. Microradiography applied to the study of foraminifera. Micropaleontology, New York, 3 (1), 19-28. 


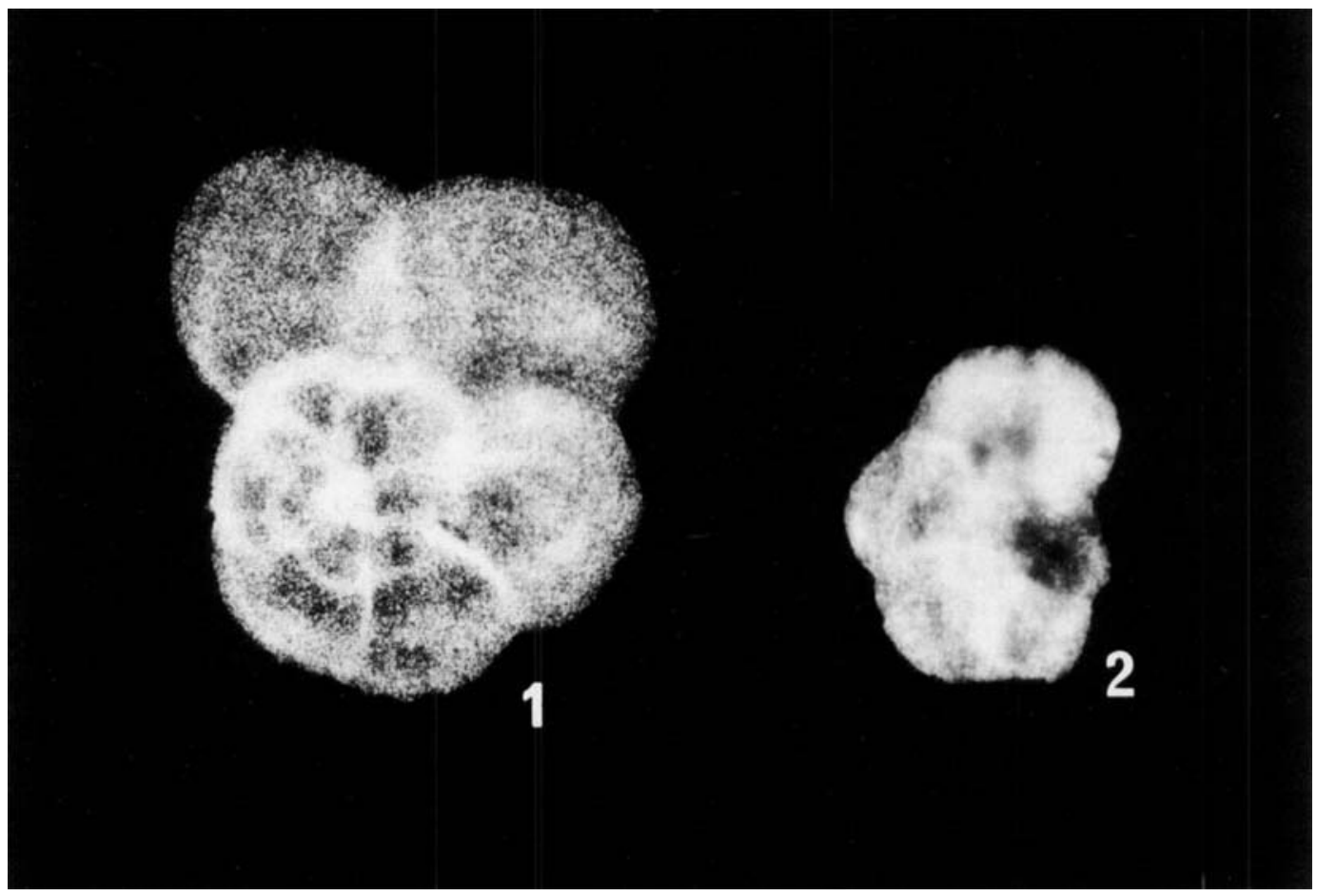

\section{Explanation of Plate 1}

Fig. 1. Rotalipora cushmani (Morrow) Site 551, DSDP Leg 80, Goban Spur.

Fig. 2. Rotalipora cushmani (Morrow) Bed 1, Plenus Marl Formation, Dover. 